\title{
Perlindungan Hukum Mitra Ojek Daring di Indonesia
}

\author{
M. Kharis Mawanda \\ University of Jember, Indonesia \\ mawandakharis@gmail.com
}

Adam Muhshi

University of Jember, Indonesia

adammuhshi.fh@unej.ac.id

\begin{abstract}
As one of the countries with the highest population density in the world, the opportunity to work in Indonesia is not directly proportional to its population density so that the number of unemployed is still relatively high. The development of technology has entered in business and it is seen as an alternative with its emergence of the online transportation service providers such as Go-Jek. In the case of partnership agreements used by partners with Go-Jek, partners as parties that have weak bargaining power while Go-Jek has strong bargaining power. From a legal standpoint, the main problem is the absence of legislation that clearly regulates online motorcycle taxis and partnership agreements between partners and Go-Jek. Therefore, it is necessary to analyze the online motorcycle taxi, and the legal protection aspects against partners based on partnership agreements and legal remedies in the event of a dispute in the implementation of the partnership agreement. With doctrinal research, this article argues that the partnership agreement is an agreement on innominaat so that in its implementation it should not conflict with the laws and regulations on it. The results of the study indicate that online motorcycle taxis have not yet been regulated in Indonesian laws and regulations, the partnership agreement has not provided legal protection for partners and in the event of a dispute, there can be legal action in accordance with the partnership agreement clause.
\end{abstract}

KEYWORDS: Legal Protection, Partnership Agreement, Online Taxi.

Copyright $\odot 2019$ by Author(s)

This work is licensed under a Creative Commons Attribution-ShareAlike 4.0 International License. All writings published in this journal are personal views of the authors and do not represent the views of this journal and the author's affiliated institutions.

\section{HOW TO CITE:}

Mawanda, M. Kharis \& Adam Muhshi. "Perlindungan Hukum Mitra Ojek Daring di Indonesia" (2019) 6:1 Lentera Hukum 35-54.

Submitted: December 10, 2018 Revised: February 17, 2019 Accepted: April 28, 2019 


\section{PENDAHULUAN}

Bekerja merupakan salah satu hak setiap orang untuk memenuhi kebutuhan hidupnya. Hak tersebut sebagaimana dalam ketentuan Pasal 27 ayat (2) Undang-Undang Dasar Negara Republik Indonesia Tahun 1945 (selanjutnya disebut UUD NRI Tahun 1945) yang menyatakan bahwa "Tiap-tiap warga negara berhak atas pekerjaan dan penghidupan yang layak bagi kemanusiaan”. Ketentuan ini dipertegas lagi dalam Pasal 28 D ayat (2) yang menyatakan bahwa "Setiap orang berhak untuk bekerja serta mendapat imbalan dan perlakuan yang adil dan layak dalam hubungan kerja".

Tetapi permasalahan yang ada saat ini, pemerintah belum mampu menyediakan lapangan pekerjaan yang cukup untuk menampung tenaga kerja. Mengingat juga perbandingan jumlah tenaga kerja yang dibutuhkan lebih kecil dari jumlah pencari kerja. Oleh karena itu, sektor swasta ikut berperan dalam upaya penyediaan lapangan pekerjaan dan penyerapan tenaga kerja yang sesuai dengan spesifikasi tenaga kerja yang dibutuhkan oleh pihak swasta tersebut. Namun sama halnya dengan pemerintah, sektor swasta juga belum mampu menyerap besarnya jumlah pencari kerja yang ada.

Karena terbatasnya lapangan pekerjaan menyebabkan meningkatnya jumlah pengangguran yang bersamaan dengan meningkatnya pula angka kemiskinan. Pengangguran dan kemiskinan merupakan momok bagi negara Indonesia. Kurangnya masyarakat yang sadar akan pentingnya pendidikan menjadi faktor terbesar penyumbang angka pengangguran. Di samping itu, juga membuat masyarakat beralih bekerja di berbagai bidang usaha ekonomi informal dengan ciri-ciri antara lain usaha berskala mikro, tempat usaha tidak tetap, usaha dengan modal kecil, jam kerja tidak teratur, menghasilkan barang dan/atau jasa kualitas rendah, menggunakan teknologi sederhana, tingkat produktivitas rendah, mobilitas tenaga kerja tinggi, penghasilan tidak tetap serta kelangsungan usaha tidak terjamin. ${ }^{1}$ Misalnya supir angkot, tukang becak, petani, nelayan, pengamen jalanan, pekerja rumah tangga, pedagang kaki lima, supir ojek, dan lain sebagainya.

Perkembangan teknologi dalam dunia bisnis, yaitu di bidang startup digital (bisnis daring) telah menjadi salah satu magnet untuk memulai usaha di berbagai bidang, seperti jual beli daring, penyedia jasa daring pemesanan tiket daring dan banyak lagi yang lainnya. Saat ini yang sedang menjadi sorotan publik adalah adanya penyedia jasa transportasi daring diantaranya Go-Jek dan Grab. Dalam penelitian ini dikhususkan membahas tentang Go-Jek.

Ojek merupakan salah satu transportasi darat dengan sepeda motor plat hitam yang mengantarkan pelanggan dari satu tempat ke tempat yang lain dengan tarif tertentu. Rute perjalanan ojek disesuaikan dengan permintaan pelanggan. Ojek adalah bagian dari moda paratransit. Moda paratransit adalah sarana angkutan yang

Lihat Lampiran Peraturan Menteri Tenaga Kerja dan Transmigrasi Republik Indonesia Nomor : PER24/MEN/VI/2006 tentang Pedoman Penyelenggaraan Program Jaminan Sosial Tenaga Kerja Bagi Tenaga Kerja yang Melakukan Pekerjaan di Luar Hubungan Kerja 
mempunyai jadwal dan rute perjalanan yang tidak pasti, disesuaikan dengan keinginan penumpang. ${ }^{2}$

Apabila mengacu dari pengertian tersebut ojek sepeda motor dapat dikategorikan sebagai angkutan orang dengan kendaraan bermotor tidak dalam trayek. Ojek sampai saat ini belum mendapatkan legalitas, terbukti dengan tidak diaturnya ojek di dalam Undang-Undang Nomor 22 Tahun 2009 tentang Lalu Lintas dan Angkutan Jalan (UU LLAJ) dan Peraturan Menteri Perhubungan Republik Indonesia Nomor PM 108 Tahun 2017 tentang Penyelenggaraan Angkutan Orang dengan Kendaraan Bermotor Umum Tidak Dalam Trayek (selanjutnya disebut Permenhub No. PM 108 Tahun 2017) sebagai angkutan orang dengan kendaraan bermotor umum tidak dalam trayek.

Dalam perjanjian kemitraan tersebut merupakan perjanjian yang berbentuk baku (standard contract). Sutan Remy Sjahdeini menyatakan bahwa perjanjian baku adalah perjanjian yang hampir seluruh klausul-klausulnya sudah dibakukan oleh pemakainya dan pihak yang lain pada dasarnya tidak mempunyai peluang untuk merundingkan atau meminta perubahan. ${ }^{3}$

Perjanjian kemitraan ini sebelumnya sudah dibuat oleh Go-Jek tanpa melibatkan mitra. Mitra yang akan bekerjasama dengan Go-Jek hanya mempunyai 2 (dua) pilihan yaitu setuju/sepakat dan tidak setuju/tidak sepakat dengan perjanjian kemitraan tersebut. Jika tidak setuju/tidak sepakat maka mitra tidak bisa bekerjasama dan menggunakan Aplikasi Go-jek tersebut. Dan jika setuju/sepakat maka mitra terikat dengan perjanjian kerjasama kemitraan tersebut. Dalam perspektif KUHPerdata dapat dilihat dalam rumusan Pasal 138 ayat (1) yang menyatakan bahwa "semua perjanjian yang dibuat secara sah berlaku sebagai undang-undang bagi mereka yang membuatnya". A Apabila salah satu pihak melakukan pelanggaran terhadap klausul dari perjanjian tersebut maka akan dikenai sanksi sebagaimana pelanggaran terhadap undang-undang. ${ }^{5}$ Hal tersebut membuat ketidakseimbangan dalam perjanjian kemitraan elektronik antara Go-Jek dengan mitra.

Terkait dengan permasalahan tersebut, pembahasan dalam artikel ini akan dibagi menjadi tiga bagian. Pertama, pengaturan ojek daring dalam peraturan perundangundangan di Indonesia. Kedua, analisis perjanjian kemitraan antara mitra ojek daring dengan PT. Go-Jek Indonesia menurut peraturan perundang-undangan di Indonesia. Ketiga, upaya hukum yang dapat dilakukan mitra ojek daring apabila terjadi perselisihan dalam pelaksanaan perjanjian kemitraan. Keseluruhan topik tersebutlah yang akan menjadi pedoman alur analisis atau pokok bahasan.

2 Vuchic, Vukan R, Urban Passenger Transportation Modes, Public Transportation, Second Edition, (New Jersey: eds. Gray, George E dan Hoel, Lester A, Prentice Hall, Englewood liffs, 1992), at 76.

3 H. Salim HS, Perkembangan Hukum Kontrak di Luar KUH Perdata, (Jakarta: PT. Raja Grafindo Persada, 2006), at 146.

4 Rendy Saputra, Kedudukan Penyalahgunaan Keadaan (Misbruik van Omstandigheden) dalam Hukum Perjanjian Indonesia, (Yogyakarta: Gadjah Mada University Press, 2016), at 19-20.

5 Gunawan \& Johanes, "Reorientasi Hukum Kontrak di Indonesia", (2003) Jurnal Hukum Bisnis: Vol. 22 No. 6 , at 48 . 


\section{PENGATURAN OJEK DARING DI INDONESIA}

Fenomena kehadiran ojek daring di Indonesia sebagai moda transportasi yang memudahkan dan menguntungkan bagi mitra ojek daring serta konsumen, membuat ojek daring saat ini sedang ramai diperbincangkan di media, maupun di dunia bisnis. Pasalnya ojek daring telah berhasil memikat hati masyarakat baik yang akan menjadi mitra ojek daring maupun yang akan menikmati jasa dari ojek daring. Kehadiran ojek daring terbukti dapat mengurangi angka pengangguran di Indonesia.

Berdasarkan lapangan pekerjaan utama, jumlah penduduk yang bekerja naik hampir di semua sektor bila dibandingkan Agustus 2015, kecuali sektor konstruksi. Peningkatan jumlah tenaga kerja terutama di sektor jasa kemasyarakatan sebanyak 1,52 juta orang (8,47 persen). Kemudian sektor perdagangan sebanyak 1,01 juta orang $(3,93$ persen), serta sektor transportasi, pergudangan, dan komunikasi sebanyak 500 ribu orang (9,78 persen). Sementara sektor konstruksi berkurang jumlah tenaga kerjanya sebanyak 230 ribu orang (2,80 persen). "Di sektor transportasi contohnya, ada kenaikan jumlah tenaga kerja karena ada angkutan ojek motor atau ojek daring. Terutama di wilayah DKI Jakarta yang kenaikannya lumayan tinggi, orang yang bekerja di Gojek, atau ojek daring lainnya," kata Kecuk. Kenaikan jumlah tenaga kerja di sejumlah sektor ini, ia mengakui, sangat membantu mengurangi angka pengangguran di Indonesia, terutama di perkotaan. Jumlah orang yang menganggur di Agustus 2016 sebanyak 7,03 juta atau turun 530 ribu orang dalam kurun waktu setahun lalu yang realisasinya 7,56 juta orang. ${ }^{6}$

Pada dasarnya ojek daring adalah sama dengan ojek-ojek yang lain, hanya saja ojek daring adalah ojek yang terintegrasi dengan internet dalam hal pelaksanaannya yang mana dapat dipesan hanya melalui Aplikasi Go-Jek, definisi ojek sendiri menurut J.S. Badudu dan Sutan Mohammad Zain dalam kamus umum bahasa Indonesia adalah sepeda motor yang dibuat menjadi kendaraan umum untuk membonceng penumpang ketempat tujuannya. ${ }^{7}$ Ojek adalah sarana transportasi darat yang menggunakan kendaraan roda dua (sepeda motor) dengan berplat hitam, untuk mengangkut penumpang dari satu tujuan ke tujuan lainnya dengan menarik bayaran. Ojek melayani rute perjalanan sesuai permintaan penumpang. Dalam hal ini ojek adalah bagian dari moda paratransit. Rute perjalanan ojek disesuaikan dengan permintaan pelanggan. Ojek adalah bagian dari moda paratransit. Moda paratransit adalah sarana angkutan yang mempunyai jadwal dan rute perjalanan yang tidak pasti, disesuaikan dengan keinginan penumpang. ${ }^{8}$

Dalam pelaksanaannya, keberadaan ojek dalam lingkungan masyarakat dianggap sangat membantu dalam pemenuhan kebutuhan transportasi angkutan umum alternatif. Alasan masyarakat memilih jasa ojek dikarenakan bisa menjangkau tempat yang tidak dapat dilalui oleh angkutan lainnya, seperti angkutan kota (angkot), bus,

\footnotetext{
6 "Kehadiran Ojek Online Kurangi Pengangguran - Bisnis Liputan6.com", online: 〈https://www.liputan6.com/bisnis/read/2645780/kehadiran-ojek-online-kurangi-pengangguran〉.

7 J.S. Badudu \& Mohammad Zain, Kamus Umum Bahasa Indonesia, (Jakarta: PT. Intergraphic, 1994), at 48.

8 Vuchic, Vukan R, supra note 2 at 76.
} 
atau jenis angkutan umum beroda empat lainnya. Ojek juga dinilai cepat dan efisien untuk menghindari kemacetan di jalan raya, yang mana ojek dapat masuk ke dalam gang-gang, dan jalan kecil yang sulit dijangkau oleh alat transportasi lainnya.

Ojek dinilai oleh masyarakat telah membantu dalam pemenuhan kebutuhan transportasi angkutan umum dikarenakan kecepatan dan efisiensinya. Namun hal tersebut ternyata tidak sejalan dengan regulasi di Indonesia. Ojek yang menggunakan sepeda motor sebagai angkutan umum dianggap bermasalah dalam hal legalitas. Pada dasarnya di dalam UU LLAJ, tidak ada pasal yang secara tegas melarang beroperasinya ojek sepeda motor sebagai angkutan umum. Apabila mengacu pada UU LLAJ, ojek termasuk dalam klasifikasi kendaraan bermotor umum, sebagaimana diatur dalam Pasal 1 angka 10 yang mendefinsikan kendaraan bermotor umum, berikut Pasal 137 ayat (2) menyebutkan angkutan orang dengan kendaraan bermotor terdiri atas motor, mobil penumpang, atau bus. Selain itu, Pasal 138 ayat (3) yang menyebutkan penggolongan angkutan umum bagi orang maupun barang hanya berupa kendaraan bermotor umum.

Ojek sepeda motor dalam kesehariannya bekerja layaknya angkutan orang dengan kendaraan bermotor umum tidak dalam trayek. Ojek tidak mempunyai tujuan perjalanan tetap, serta lintasan tetap seperti angkutan orang dengan kendaraan umum dalam trayek yaitu bus umum atau angkutan kota (angkot). Tetapi ojek hanya mengatarkan penumpang sesuai tujuan yang dikehendakinya.

Angkutan orang dengan kendaraan bermotor umum tidak dalam trayek diatur di dalam Permenhub No. PM 108 Tahun 2017. Dalam Permenhub tersebut tidak menyebutkan sepeda motor sebagai angkutan orang dengan kendaraan bermotor umum tidak dalam trayek. Dalam Pasal 1 angka 3 menyatakan "Angkutan Orang dengan Kendaraan Bermotor Umum Tidak Dalam Trayek adalah angkutan yang dilayani dengan mobil penumpang umum atau mobil bus umum dalam wilayah perkotaan dan/atau kawasan tertentu atau dari suatu tempat ke tempat lain, mempunyai asal dari suatu tempat ke tempat lain, mempunyai asal dan tujuan tetapi tidak mempunyai lintasan dan waktu tetap." Sehingga ojek dengan menggunakan sepeda motor bukan merupakan angkutan orang dengan kendaraan bermotor tidak dalam trayek. Dalam UU No. 22 Tahun 2009 dan Permenhub No. PM 108 Tahun 2017 tidak menyebutkan larangan beroperasinya ojek sepeda motor. Apabila dilihat dari segi regulasi, ojek sepeda motor tidak mempunyai legalitas untuk beroperasi sebagai angkutan orang, tetapi hanya diakui sebagai kendaraan bermotor umum.

Salah satu perusahaan di Indonesia yang bergerak di bidang bisnis ojek daring adalah PT. Go-Jek Indonesia. Dalam Pasal 139 ayat (4) UU LLAJ menyebutkan "Penyediaan jasa angkutan umum dilaksanakan oleh badan usaha milik negara, badan usaha milik daerah, dan/atau badan hukum lain sesuai dengan ketentuan peraturan perundang-undangan." PT. Go-Jek Indonesia merupakan perusahaan berbadan hukum yang berbentuk Perseroan Terbatas (PT) tetapi PT. Go-Jek Indonesia bukan perusahaan yang bergerak di bidang transportasi, melainkan perusahaan teknologi sebagai penyedia aplikasi. Di dalam situs resmi PT. Go-Jek Indonesia menyebutkan "GO-JEK adalah sebuah perusahaan teknologi berjiwa sosial yang bertujuan untuk 
meningkatkan kesejahteraan pekerja di berbagai sektor informal di Indonesia. Kegiatan GO-JEK bertumpu pada 3 nilai pokok: kecepatan, inovasi, dan dampak sosial."9

Selain itu juga disebutkan "Untuk menghindari keragu-raguan, kami adalah perusahaan teknologi, bukan perusahaan transportasi atau kurir dan kami tidak memberikan layanan transportasi atau kurir. Kami tidak mempekerjakan Penyedia Layanan dan kami tidak bertanggung jawab atas setiap tindakan dan/atau kelalaian Penyedia Layanan. Aplikasi ini hanya merupakan sarana untuk memudahkan pencarian atas Layanan. Adalah tergantung pada Penyedia Layanan untuk menawarkan Layanan kepada Anda dan tergantung pada Anda apakah Anda akan menerima tawaran Layanan dari Penyedia Layanan." ${ }^{10}$ Dari pernyataan tersebut jelas bahwa PT. Go-Jek Indonesia merupakan perusahaan teknologi yang menyediakan Aplikasi untuk pengendara ojek daring, bukan merupakan perusahaan angkutan umum sebagaimana yang dimaksud dalam UU LLAJ.

\section{ANALISIS PERJANJIAN KEMITRAAN ANTARA MITRA OJEK DARING DENGAN PT. GO-JEK INDONESIA}

Pengertian hubungan kerja dalam Pasal 1 angka 15 Undang-Undang Nomor 13 Tahun 2003 tentang Ketenagakerjaan (UU Ketenagakerjaan) mendefinisikan bahwa hubungan kerja adalah hubungan antara pengusaha dengan pekerja/buruh berdasarkan perjanjian kerja, yang mempunyai unsur pekerjaan, upah, dan perintah. Dilihat dari pengertian tersebut berarti adanya suatu hubungan kerja timbul dikarenakan adanya perjanjian kerja, bukan dikarenakan adanya perjanjian kemitraan. Perjanjian kemitraan sendiri hanya akan menimbulkan suatu hubungan kerjasama. Sedangkan perjanjian kerja menurut Pasal 1 angka 14 UU Ketenagakerjaan mendefinisikan bahwa perjanjian kerja adalah perjanjian antara pekerja/buruh dengan pengusaha atau pemberi kerja yang memuat syarat-syarat kerja, hak, dan kewajiban para pihak.

Hubungan hukum yang tercipta antara Go-Jek, AKAB, dan mitra adalah hubungan kerjasama kemitraan yang berdasarkan perjanjian kerjasama kemitraan, perlindungan hukum terhadap mitra ojek daring bukan perlindungan bagi pekerja yang berdasarkan perjanjian kerja, melainkan perlindungan sebagai pihak dalam sebuah perjanjian kerjasama kemitraan. Dengan demikian maka UU Ketenagakerjaan tidak bisa diterapkan dalam perjanjian kerjasama kemitraan ini, melainkan hubungan kerjasama yang timbul dalam perjanjian kerjasama kemitraan ini adalah sebagai perjanjian biasa dengan perusahaan yaitu bentuk umum suatu hubungan hukum antara satu pihak dengan pihak lainnya atas dasar hubungan kerjasama, yang mana tunduk pada aturan dalam Kitab Undang-Undang Hukum Perdata (KUHPerdata).

Pada dasarnya suatu kontrak berawal dari suatu perbedaan atau ketidaksamaan kepentingan diantara para pihak. Perumusan hubungan kontraktual tersebut pada umumnya senantiasa diawali dengan proses negosiasi tersebutlah para pihak berupaya

\footnotetext{
9 "Tentang Kami | GO-JEK Indonesia", online: ‘https://www.go-jek.com/about/》.

10 "GO-JEK Indonesia", online: 〈https://www.go-jek.com/s.
} 
menciptakan bentuk-bentuk kesepakatan untuk saling menguntungkan atau saling mempertemukan sesuatu yang diinginkan (kepentingan) melalui proses tawarmenawar.

Pendek kata, pada umumnya sebuah kontrak ataupun perjanjian sering kali berawal dari perbedaan kepentingan yang coba dipertemukan melalui proses negosiasi kontrak pada fase prakontrak. Melalui proses negosiasi pada fase prakontrak, berbagai perbedaan dan kepentingan masing-masing pihak dinegosiasikan, kemudian dipertemukan, selanjutnya dibingkai dengan perangkat hukum yang disebut kontrak sehingga bisa mengikat para pihak. ${ }^{11}$

Dalam peraturan perundang-undangan di Indonesia belum ditemukan pengertian dari perjanjian kemitraan, berarti telah terjadi adanya kekosongan hukum. Cara yang dapat dilakukan apabila terjadi kekosongan hukum dalam perjanjian kemitraan adalah dengan memahami konstruksi hukumnya. Perjanjian kemitraan sendiri merupakan salah satu bentuk perjanjian tidak bernama. Perjanjian tidak bernama telah diatur dalam Pasal 1319 KUHPerdata, yaitu "Semua perjanjian baik yang mempunyai nama khusus maupun yang tidak dikenal dengan suatu nama tertentu, tunduk pada peraturan umum yang termuat dalam bab ini dan bab yang lain".

Meskipun tidak diatur secara rinci di dalam KUHPerdata, namun ketentuan mengenai keabsahan kontrak hingga batal ataupun putusnya kontrak tersebut berlaku sama seperti pengaturan perjanjian bernama. Dimana seperti yang telah dijelaskan sebelumnya, bahwa keabsahan suatu kontrak diatur dalam pasal 1320 KUHPerdata yaitu kesepakatan, kecakapan, objek tertentu, dan kausa yang diperbolehkan.

Dalam pengaturannya, kontrak kemitraan ini diatur berdasarkan asas kebebasan berkontrak (freedom of contract). Dalam asas kebebasan berkontrak para pihak bebas membuat klausula-klausula serta berbagai kesepakatan yang mereka sepakati. Prinsip kebebasan berkontrak sendiri diwujudkan dalam 5 (lima) bentuk prinsip hukum, yaitu kebebasan menentukan isi kontrak, kebebasan menentukan bentuk kontrak, kontrak mengikat sebagai undang-undang, aturan memaksa (mandatory rules) sebagai perkecualian, dan sifat internasional dan tujuan prinsip-prinsip UNIDROIT yang harus diperhatikan dalam penafsiran kontrak. Kebebasan para pihak untuk memilih hukum mana yang berlaku, tidak berarti bahwa pilihan boleh dilakukan secara sewenangwenang karena terdapat berbagai pembatasan, yaitu sepanjang tidak melanggar kepentingan umum, tidak boleh menjadi suatu penyelundupan hukum, dan hanya boleh dilangsungkan berkenaan dengan bidang hukum perjanjian.

Dalam pembuatan kontrak kemitraan tersebut pun hendaknya unsur fundamental right (hak dasar) menjadi acuan di dalamnya. Sehingga, dengan adanya unsur tersebut kepastian hukum para pihak terjamin dengan baik, dimana dalam substansi kontrak tersebut tidak lebih memberatkan pada kepentingan salah satu pihak saja, namun harus memperhatikan kepentingan seluruh pihak yang terkait dengannya secara langsung maupun tidak langsung.

"Hernoko \& Agus Yudha, Asas Proporsionalitas dalam Kontrak Komersial Edisi 1, (Yogyakarta: Laksbang Mediatama bekerja sama dengan Kantor Advokat "Hufron \& Hans Simalea", 2008), at 2. 
Pengaturan kemitraan diatur dalam Pasal 1 angka 4 Peraturan Pemerintah Nomor 17 Tahun 2013 tentang Pelaksanaan Undang-Undang Nomor 20 tahun 2008 tentang Usaha Mikro, Kecil, dan Menengah (selanjutnya disebut PP No. 17 Tahun 2013), disebutkan bahwa "Kemitraan adalah kerja sama dalam keterkaitan usaha, baik langsung maupun tidak langsung, atas dasar prinsip saling memerlukan, mempercayai, memperkuat, dan menguntungkan yang melibatkan pelaku Usaha Mikro, Kecil dan Menengah dengan Usaha Besar." Dalam kemitraan terdapat prinsip saling memerlukan, saling memperkuat dan saling menguntungkan, yang akan terjalin karena para mitra akan dan saling mengenal posisi keunggulan dan kelemahan masing-masing yang akan berdampak pada efisiensi dan turunnya biaya produksi. Karena kemitraan didasarkan pada win win solution partnership (kerjasama yang saling menguntungkan), maka para mitra akan mempunyai posisi tawar yang akan setara yang berdasarkan peran masingmasing. Ciri kemitraan adalah kesejajaran kedudukan, tidak ada pihak yang dirugikan dan bertujuan untuk meningkatkan keuntungan bersama melalui kerjasama tanpa saling mengeksploitasi satu dengan yang lain dan tumbuhnya rasa saling percaya diantara mereka. ${ }^{12}$ Dalam Pasal 11 ayat (2) PP No. 17 Tahun 2013 telah disebutkan bahwa kemitraan dapat dilaksanakan antara lain dengan pola inti-plasma, sub kontraktor, waralaba, perdagangan umum, distribusi dan keagenan, bagi hasil, kerja sama operasional, usaha patungan (joint venture), penyumberluaran (outsourching), dan bentuk kemitraan lainnya.

Terdapat dua bentuk perjanjian kemitraan antara Go-jek dan mitra, yaitu bentuk tertulis berupa Surat Keterangan Kemitraan dan bentuk elektronik berupa Perjanjian Kemitraan yang terdapat pada aplikasi Driver Go-Jek. Perjanjian yang berbentuk tertulis, mitra yang setuju menandatangani surat tersebut. Perjanjian yang berbentuk elektronik lebih lengkap dari perjanjian tertulis, mitra yang setuju dengan perjanjian tersebut melakukan persetujuan dengan cara meng-klik persetujuan tersebut dan selanjutnya aplikasi dapat digunakan.

Dalam Pasal 5.6 (a) perjanjian kemitraan disebutkan bahwa "Perjanjian ini merupakan keseluruhan perjanjian dan pemahaman antara mitra dengan GO-JEK dan/atau AKAB berkenaan dengan permasalahan pokok serta menukar dan menggantikan semua perjanjian atau kesanggupan terdahulu antara mitra dengan GOJEK dan/atau AKAB mengenai permasalahan pokok tersebut. Dalam hal mitra sudah sebelumnya menyetujui dan/atau menandatangani perjanjian serupa dengan GO-JEK, maka perjanjian tersebut akan dilanjutkan dan digantikan dengan Perjanjian ini dengan syarat dan ketentuan sebagaimana diatur dalam Perjanjian ini."

Dalam klausula perjanjian kemitraan di atas dapat diketahui bahwa ketika mitra telah meng-klik perjanjian kemitraan yang terdapat pada aplikasi tersebut maka perjanjian sebelumnya yang telah ditandatangani oleh Go-Jek dan mitra telah digantikan dengan perjanjian kemitraan yang ada dalam aplikasi sehingga perjanjian tertulis yang ditandatangani sudah tidak berlaku lagi. Oleh karena itu hanya terdapat

12 Ian Linton, Kemitraan Meraih Keuntungan Bersama, (Jakarta: Hailarang, 1997), at 10. 
satu perjanjian yang berlaku bagi Go-Jek dan mitra yaitu perjanjian kemitraan yang terdapat pada aplikasi Driver Go-Jek.

Dalam perjanjian kerjasama kemitraan tersebut, ditemukan banyak klausula yang hanya berpihak pada Go-Jek dan AKAB serta banyak juga ditemukan kebijakan sepihak, seperti beberapa klausula dalam perjanjian kemitraan di bawah ini :

a. Pasal 2 (c) Perjanjian Kemitraan

"AKAB, sebagai pemilik dari Aplikasi GO-JEK, atas dasar pertimbangannya sendiri, dapat mengubah atau menambahkan Persyaratan dari waktu ke waktu. Perubahan atau penambahan atas Persyaratan tersebut akan berlaku setelah AKAB mengumumkan perubahan atau penambahan Persyaratan tersebut melalui media elektronik ataupun media komunikasi lain yang dipilih AKAB yang dapat mencakup perubahan atau penambahan kebijakan yang sudah ada dalam persyaratan atau syarat dan ketentuan tambahan. Mitra menyetujui bahwa akses atau penggunaan mitra yang berkelanjutan atas Aplikasi GO-JEK maupun kelanjutan kerjasama mitra setelah tanggal pengumuman atas perubahan Persyaratan akan diartikan bahwa mitra setuju untuk terikat oleh Persyaratan, sebagaimana telah diubah atau ditambahkan."

b. Pasal 5.2 (c) Perjanjian Kemitraan

"Para Pihak setuju dan sepakat bahwa segala perubahan, amandemen atas Perjanjian ini dan Persyaratan (termasuk syarat dan ketentuan untuk penggunaan fitur fitur lain dalam Aplikasi GO-JEK), perubahan mana dapat dilakukakan oleh GO-JEK, AKAB atau pihak Afiliasi GO-JEK maupun AKAB atas dasar pertimbangannya sendiri, juga dapat dibuat secara Elektronik. Perubahan atas Perjanjian ini atau Persyaratan akan berlaku setelah GO-JEK atau AKAB mengumumkan perubahan Persyaratan tersebut baik melalui Aplikasi Go-Jek ataupun melalui media lainnya yang dipilih oleh GO-JEK ataupun AKAB dan mitra menyetujui bahwa akses atau penggunaan mitra yang berkelanjutan atas Aplikasi GO-JEK ataupun AKAB setelah tanggal pengumuman atas perubahan syarat dan ketentuan dalam persyaratan akan diartikan bahwa mitra setuju untuk terikat oleh Persyaratan, sebagaimana telah diubah atau ditambahkan.”

Berdasarkan klausula dalam perjanjian kemitraan di atas, dapat diketahui bahwa di dalam perjanjian kemitraan tersebut Go-Jek dalam membuat perjanjian banyak menggunakan "atas dasar pertimbangannya sendiri" yang mana tidak melibatkan mitra sebagai pihak yang mengikatkan diri di dalam perjanjian. Klausula tersebut menyebabkan Go-Jek dan AKAB mempunyai hak untuk kapanpun dapat merubah, menambah, atau menghapus persyaratan dan kebijakan dalam Aplikasi Go-Jek secara sepihak tanpa dirundingkan dengan mitra. Dapat diartikan bahwa mitra menerima persyaratan tanpa turut andil di dalam proses penambahan atau perubahan persyaratan dan/atau kebijakan dalam perjanjian. 
Selain itu, demikian juga dalam pengambilan bagian dari setiap pembayaran yang diterima oleh mitra dari konsumen seperti dalam Pasal 3.3 (a) dan (b) Perjanjian Kemitraan berikut ini:

(a) Mitra menyetujui bahwa harga dan struktur pembayaran oleh penerima jasa atas jasa yang disediakan oleh mitra dengan menggunakan Aplikasi GO-JEK ("Konsumen"), termasuk biaya pembatalan pemesanan oleh konsumen adalah harga yang ditunjukan melalui Aplikasi GO-JEK.

(b) Mitra menyetujui bahwa AKAB dapat:

i. Menentukan harga yang harus dibayarkan oleh konsumen sesuai dengan ketentuan perundang-undangan yang berlaku, perubahan mana akan diberitahukan kepada mitra secara tertulis (baik melaului Aplikasi GO-JEK ataupun melalui media komunikasi lainnya yang dipilih oleh AKAB);

ii. Mengambil bagian dari setiap pembayaran yang diterima oleh mitra dari Konsumen atas jasa yang disediakan oleh mitra kepada Konsumen untuk penggunaan Aplikasi GO-JEK, dimana jumlah pembagian hasil adalah berdasarkan persentase tertentu atas jumlah yang diterima dari Konsumen (yang sudah termasuk pajak pertambahan nilai) dan dapat diberlakukan sewaktu waktu oleh AKAB dan akan diberitahukan kepada mitra secara tertulis (baik melalui Aplikasi GO-JEK ataupun melalui media lainnya yang dipilih oleh AKAB); dan

iii. Untuk menarik jumlah pembayaran dari rekening bank mitra pada bank yang ditunjuk oleh $\mathrm{AKAB}$ ataupun afiliasi dari $\mathrm{AKAB}$ untuk melakukan penarikan jumlah yang ditentukan oleh AKAB untuk keperluan pembagian hasil sebagaimana dinyatakan dalam pasal 2 di atas atau pembagian hasil yang dihitung berdasarakan cara lain yang ditentukan oleh AKAB, atau untuk membayar uang penalti atas pelanggaran yang dilakukan oleh mitra.

AKAB dapat mengambil bagian dari setiap pembayaran yang diterima oleh Mitra dari konsumen melalui saldo yang diambil pada setiap transakasi yang dilakukan oleh mitra. Tetapi di dalam Pasal 3.3 huruf b yang perlu digaris bawahi yaitu jumlah pembagian hasil adalah berdasarkan persentase tertentu atas jumlah yang diterima dari Konsumen (yang sudah termasuk pajak pertambahan nilai). Dalam pasal tersebut tidak disebutkan dengan jelas berapa "persentase tertentu" yang dimaksud. Dan kebijakan pembagian hasil tersebut dapat berubah atau ditambah secara sepihak oleh Go-Jek dan AKAB sebagaimana yang dijelaskan dalam Pasal 5.2 (c) di atas. Hal tersebut menyebabkan kenaikan tarif dan pembagian hasil yang hanya dikontrol oleh Go-Jek dan AKAB tanpa campur tangan dari mitra.

Dari klausula-klausula yang dijabarkan di atas menunjukkan adanya ketidakseimbangan dalam perjanjian kemitraan ini. Hal tersebut tidak sejalan dengan Pasal 1 angka 4 PP No. 17 Tahun 2013 bahwa kerjasama usaha haruslah didasari kesejajaran kedudukan dan mempunyai derajat yang sama bagi para pihak yang bermitra, tidak ada pihak yang dirugikan dalam kemitraan dengan tujuan bersama 
untuk meningkatkan keuntungan atau pendapatan melalui pengembangan usaha tanpa saling mengeksploitasi satu sama lain serta saling berkembangnya rasa saling percaya diantara mereka. Go-Jek seharusnya menempatkan para pihak di posisi yang setara sebagai mitranya. Mitra secara tidak langsung harus mematuhi perjanjian kemitraan tersebut. Karena, dalam Pasal 1338 ayat (1) KUHPerdata menyatakan bahwa "semua perjanjian yang dibuat secara sah berlaku sebagai undang-undang bagi mereka yang membuatnya".

Hal ini juga berakibat mitra ojek daring melakukan aksi demo, salah satunya yang dilakukan di depan Gedung MPR/DPR/DPD, Senayan Jakarta pada tanggal 23 April 2018. Mereka menuntut pemerintah untuk segera menertibkan peraturan perundangan sebagai payung hukum bagi kelangsungan dan pekerjaan ojek daring, serta meminta penetapan tarif standar dengan nilai yang wajar, yaitu Rp. 3 ribu sampai dengan Rp. 4 ribu per kilometer. Tentunya dengan metode subsidi dari perusahaan aplikasi, agar tarif bagi penumpang tetap murah dan terjangkau. Serta menuntut adanya perlindungan hukum dan keadilan bagi ojek daring sebagai bagian dari tenaga kerja Indonesia yang mandiri. ${ }^{13}$

Fenomena adanya ketidakseimbangan dalam berkontrak sebagaimana tersebut di atas dapat dicermati dalam beberapa model kontrak, terutama kontrak-kontrak konsumen dalam bentuk standar/baku yang di dalamnya memuat klausul-klausul yang isinya (cenderung) berat sebelah. Supaya proses pertukaran dalam kontrak berjalan secara adil, para pihak dituntut untuk memahami dasar-dasar hukum kontrak. Mengapa pemahaman ini diperlukan? Perlu diingat bahwa kontrak yang dibuat atau disusun oleh para pihak pada dasarnya merupakan penuangan proses bisnis ke dalam rumusan bahasa hukum (kontrak). Dengan memahami dasar hukum kontrak, dimaksudkan para pihak mempunyai pedoman dalam penyusunan kontrak karena memberikan dasar hukum bagi kontrak yang dibuat, mmberikan bingkai atau ramburambu atau aturan main dalam transaksi bisnis, dan bagai batu uji atau tolak ukur eksistensi kontrak yang bersangkutan. ${ }^{14}$

Menurut hukum perjanjian kita, seseorang bebas membuat perjanjian dengan pihak mana pun yang dikehendakinya. Undang-undang hanya mengatur orang-orang tertentu yang tidak cakap membuat perjanjian. ${ }^{15}$ Sehingga dapat diartikan bahwa setiap orang bebas untuk memilih dengan pihak mana ia akan membuat perjanjian.

Dalam hal ini dapat dilihat dalam asas kebebasan berkontrak yang mana asas ini memberikan kebebasan kepada pihak untuk membuat atau tidak membuat perjanjian, mengadakan perjanjian dengan siapapun, menentukan isi perjanjian/pelaksanaan dan persyaratannya, menentukan bentuknya perjanjian yaitu tertulis atau lisan. Asas berkontrak yang dianut hukum Indonesia tidak terlepas kaitannya dengan Sistem

\footnotetext{
13 "Kisruh Demo Driver Ojek Online di DPR, Go-Jek Bakal Lakukan Apa? - Tekno Liputan6.com”, online: 〈https://www.liputan6.com/tekno/read/3483830/kisruh-demo-driver-ojek-online-di-dpr-go-jekbakal-lakukan-apà.

14 Hernoko \& Agus Yudha, supra note 11 at 86.

15 Lihat Pasal 1330 KUHPerdata
} 
Terbuka yang dianut. Buku III KUHPerdata merupakan hukum pelengkap yang boleh dikesampingkan oleh para pihak yang membuat perjanjian. ${ }^{16}$

Seiring dengan perkembangan zaman, asas kebebasan berkontrak kini tidak lagi terbatas. Negara telah melakukan sejumlah pembatasan kebebasan berkontrak tersebut setidak-tidaknya dipengaruhi oleh dua faktor, yakni makin berpengaruhnya ajaran itikad baik tidak hanya pada pelaksanaan kontrak, tetapi juga harus ada pada saat dibuatnya kontrak, serta makin berkembangnya ajaran penyalahgunaan keadaan (misbruik van omstandigheden atau undue influence). ${ }^{17}$

Kebebasan berkontrak yang merupakan "ruh" dan "napas" sebuah kontrak atau perjanjian, secara implisit memberikan panduan bahwa dalam berkontrak pihak-pihak diasumsikan mempunyai kedudukan yang seimbang. Dengan demikian, diharapkan akan muncul kontrak yang adil dan seimbang bagi para pihak. Namun begitu, dalam praktik masih banyak ditemukan model standar kontrak serta kontrak-kontrak yang berpotensi mengandung cacat kehendak, yakni penyalahgunaan keadaan, yang cenderung dianggap berat sebelah, tidak seimbang, dan tidak adil. ${ }^{18}$ Kontrak yang demikian sering kali diibaratkan sebagai pertarungan antara "David melawan Goliath", di mana dua kekuatan yang tidak seimbang saling berhadapan, antara pihak yang mempunyai daya tawar kuat (baik karena penguasaan modal/dana, teknologi, maupun skill yang diposisikan sebagai Goliath) dan pihak yang mempunyai daya tawar lemah (yang diposisikan sebagai David). Dengan demikian, pihak yang lemah daya tawar-nya hanya sekedar menerima segala isi kontrak dengan terpaksa (taken for granted) sebab apabila ia mencoba menawar dengan alternatif lain kemungkinan besar akan menerima konsekuensi kehilangan apa yang dibutuhkan. ${ }^{19}$ Seperti halnya dalam perjanjian kemitraan ini, Go-Jek dan AKAB sebagai pihak yang mempunyai bergaining position kuat karena merupakan perusahaan yang mempunyai Sistem Aplikasi Go-Jek, pembuat perjanjian dan mempunyai kewenangan dalam perubahan kebijakan. Sedangkan mitra sebagai pihak yang mempunyai bergaining position lemah karena merupakan perseorangan pengguna Sistem Aplikasi Go-Jek dan mengikatkan diri dalam perjanjian kemitraan. Jadi, pada sisi kontrak yang tidak berimbang tersebut hanya ada dua alternatif pilihan bagi pihak yang lemah daya tawar-nya, yakni menerima atau menolak sehingga oleh hukum diragukan apakah benar-benar ada elemen "kata sepakat" yang merupakan syarat sahnya kontrak dalam situasi-situasi tersebut. ${ }^{20}$

Terbatasnya lapangan pekerjaan dan meningkatnya kebutuhan hidup menyebabkan ribuan orang mendaftar sebagai mitra Go-jek dikarenakan persyaratan yang ditentukan juga relatif mudah. Tetapi banyak orang masih belum tahu pentingnya perjanjian yang akan mereka sepakati sebelum bermitra. Perjanjian kemitraan sering

\footnotetext{
16 Rendy Saputra, supra note 4 at 16.

17 Khairandy, Ridwan, Hukum Kontrak Indonesia dalam Perspektif Perbandingan (Bagian Pertama), (Yogyakarta: FH UII Press, 2013), at 90.

18 Rendy Saputra, supra note 4 at 50-5l.

19 Hernoko \& Agus Yudha, supra note 11 at 2-3.

20 Rendy Saputra, supra note 4 at 51.
} 
tidak dibaca terlebih dahulu oleh mitra. Mitra hanya mengetahui jika ia tidak menyetujui perjanjian tersebut maka ia tidak bisa bermitra dengan Go-Jek.

Hal tersebut mengindikasikan bahwa adanya penyalahgunaan kehendak yang telah dilakukan oleh Go-Jek sebagai daya tawar kuat. Penyalahgunaan keadaan berkaitan dengan syarat subjektif perjanjian. Salah satu pihak menyalahgunakan keadaan yang mengakibatkan pihak lawan janjiannya tidak dapat menyatakan kehendaknya secara bebas. Van Dunne membedakan penyalahgunaan menjadi 2 unsur, yaitu sangat merugikan salah satu pihak (dari segi isinya), dan penyalahgunaan kesempatan oleh pihak lain pada saat terjadinya perjanjian (dari segi terjadinya). Dari kedua unsur tersebut timbul dua sifat perbuatan, yakni yang bersumber keunggulan ekonomis dan keunggulan kejiwaan dengan persyaratan sebagai berikut: ${ }^{21}$

a. Persyaratan penyalahgunaan keunggulan ekonomis:

1. Satu pihak harus mempunyai keunggulan ekonomis terhadap yang lain;

2. Pihak lain terpaksa mengadakan perjanjian.

b. Persyaratan penyalahgunaan keunggulan psikologis atau kejiwaan:

1. Salah satu pihak menyalahgunakan ketergantungan psikologis atau kejiwaan: seperti hubungan kepercayaan istimewa antara orang tua dan anak, suami-istri, dokter-pasien, pendeta-jemaat;

2. Salah satu pihak menyalahgunakan keadaan jiwa yang istimewa dari pihak lawan, seperti adanya gangguan jiwa, tidak berpengalaman, gegabah, kurang pengetahuan, kondisi badan yang tidak baik, dan sebagainya.

Dalam hal ada kelebihan ekonomis, yang lemah mempunyai posisi "bergantung" sehingga untuk mendapatkan prestasi tertentu yang sangat dibutuhkan, ia terpaksa harus bersedia menerima janji-janji dan klausul-klasul yang sangat merugikan dirinya. Posisi finansial mendesaknya berbuat seperti itu. Lihat saja dalam hubungan yang bersifat monopolistik ketika pihak lain tak mempunyai pilihan selain menerima syaratsyarat yang diajukan oleh si pemegang monopoli. Kata orang, yang satu tak mempunyai "bargaining power". Sebagai contoh ialah hubungan antara perusahaan air minum dan pelanggannya, PT. Kereta Api Indonesia dengan penumpangnya, dan lain-lain. ${ }^{22}$

Karena posisi tawarnya yang lemah, biasanya salah satu pihak akan selalu menerima isi perjanjian bahkan terkadang tidak membacanya secara keseluruhan atau bahkan tidak dilibatkan dalam penyusunan klausul-klausul dalam kontrak ataupun perjanjian tersebut. Akibatnya, terdapat beberapa klausul perjanjian yang sebenarnya tidak masuk akal atau tidak patut atau bertentangan dengan peri kemanusiaan (ond redelijke contracts voonwaarden ataupun fair contract terms) sehingga setelah mencermati posisi para pihak sebelum menutup sebuah perjanjian, hakim seharusnya meneliti isi ataupun klausul-klausul kontrak yang dibuat secara cermat untuk menentukan adatidaknya penyalahgunaan keadaan dalam perjanjian tersebut. ${ }^{23}$

\footnotetext{
21 Henry P. Pangabean, Penyalahgunaan Keadaan (Misbruik Van Omstandigheden) Sebagai Alasan (Baru) Pembatalan Perjanjian, (Yogyakarta: Liberty, 2010), at 51.

22 Hernoko \& Agus Yudha, supra note 11 at 232.

23 Rendy Saputra, supra note 4 at 51.
} 


\section{UPAYA HUKUM ATAS POTENSI PERSELISIHAN PERJANJIAN KEMITRAAN DENGAN PERUSAHAAN OJEK DARING}

Pada hakekatnya setiap manusia ciptaan Tuhan Yang Maha Esa (YME) terlahir sebagai makhluk yang secara kodrati mendapatkan hak dasar yaitu hak hidup, kebebasan, hak untuk dilindungi, dan hak yang lainnya. Hukum sejatinya harus memberikan perlindungan terhadap semua pihak sesuai dengan status hukumnya karena setiap orang memiliki kedudukan yang sama di hadapan hukum. Setiap aparat penegak hukum jelas wajib menegakkan hukum dan dengan berfungsinya aturan hukum, maka secara tidak langsung pula hukum akan memberikan perlindungan terhadap setiap hubungan hukum atau segala aspek dalam kehidupan masyarakat yang diatur oleh hukum itu sendiri.

Menurut Fitzgerald, teori perlindungan hukum Salmond bahwa hukum bertujuan mengintegrasikan dan mengkoordinasi berbagai kepentingan dalam masyarakat karena dalam suatu lalu lintas kepentingan, perlindungan terhadap kepentingan tertentu dapat dilakukan dengan cara membantai berbagai kepentingan dilain pihak. ${ }^{24}$ Kepentingan hukum adalah hukum memiliki kekuasaan tertinggi dalam hal mengurus kepentingan dan hak manusia sehingga dapat menentukan kepentingan manusia mana yang perlu diatur dan dilindungi. ${ }^{25}$ Perlindungan hukum harus melihat tahapan bahwa perlindungan hukum itu lahir berdasar peraturan dan ketentuan hukum yang berasal dari kesepakatan masyarakat untuk mengatur hubungan antar masyarakat atau antara perseorangan dan pemerintah. Menurut Satjipto Raharjo, Perlindungan hukum adalah memberikan pengayoman terhadap hak asasi manusia (HAM) yang dirugikan orang lain dan perlindungan itu diberikan kepada masyarakat agar dapat menikmati semua hak-hak yang diberikan oleh hukum. ${ }^{26}$

Perlindungan hukum adalah perlindungan terhadap subjek hukum melalui peraturan perundang-undangan dalam pelaksanaannya bersifat memaksa dan adanya suatu sanksi. Ada dua macam perlindungan hukum, yaitu perlindungan hukum preventif dan represif.

\section{A. Perlindungan Hukum Preventif}

Perlindungan yang berasal dari pemerintah yang bertujuan guna mencegah sebelum terjadinya pelanggaran. Perlindungan ini terdapat dalam peraturan perundangundangan yang memberikan batasan atau rambu dalam melakukan kewajiwan untuk mencegah adanya pelanggaran. ${ }^{27}$ Perlindungan hukum preventif, bertujuan untuk mencegah adanya suatu sengketa. Dalam perlindungan hukum ini, sebelum adanya keputusan pemerintah yang definitif, subjek hukum diberi kesempatan untuk mengajukan keberatan (inspraak) atau pendapatnya. Perlindungan hukum preventif

Satjipto Raharjo, Ilmu Hukum, (Bandung: PT. Citra Aditya Bakti, 2000), at 53.

Ibid, at 69.

Ibid, at 34.

27 Muchsin, Perlindungan dan Kepastian Hukum bagi Investor di Indonesia, (Surakarta: Universitas Sebelas Maret, 2003), at 20 . 
sangat besar artinya bagi tindak pemerintahan yang didasarkan pada kebebasan bertindak karena dengan adanya perlindungan hukum yang preventif pemerintah terdorong untuk bersifat hati-hati dalam mengambil keputusan yang didasarkan pada diskresi. Di Indonesia belum ada pengaturan khusus mengenai perlindungan hukum preventif. ${ }^{28}$

Perlindungan hukum yang bersifat preventif dapat dilakukan oleh pemerintah melalui peraturan perundang-undangan yang dikeluarkan. Adanya UU No. 22 Tahun 2009 dan Permenhub No. PM 108 Tahun 2017 belum mengatur secara khusus mengenai ojek daring sehingga untuk beroperasi sebagai angkutan orang belum mempunyai legalitas. Oleh karena itu, untuk menjamin kepastian hukum adanya ojek daring di Indonesia diperlukan suatu undang-undang yang secara khusus mengatur mengenai masalah ojek daring secara terperinci sehingga diharapkan dapat menjadi dasar dalam penyelesaian perselisihan.

Pola kemitraan dengan bagi hasil yang digunakan Go-Jek untuk mengikatkan diri dengan mitra sampai saat ini belum diatur secara khusus dalam regulasi di Indonesia. Berbeda halnya dengan pola kemitraan waralaba yang telah diatur di dalam Peraturan Pemerintah Republik Indonesia Nomor 42 Tahun 2007 tentang Waralaba (selanjutnya disebut PP No. 42 Tahun 2007) yang terdiri dari 9 Bab di dalamnya yang dimana memuat ketentuan umum, kriteria, perjanjian waralaba, kewajiban pemberi waralaba, pendaftaran, pembinaan dan pengawasan, sanksi, ketentuan peralihan, dan ketentuan penutup.

Dengan diaturnya waralaba dalam PP No. 42 Tahun 2007 maka pemerintah telah memberikan perlindungan hukum secara preventif baik itu kepada pemberi waralaba ataupun penerima waralaba, bahkan diterapkan juga sanksi bagi pihak yang melanggar untuk meminimalisir terjadinya ketidakadilan dalam pelaksanaan perjanjian waralaba. Diaturnya waralaba tentunya tidak lepas dari menjamurnya usaha dengan menggunakan pola waralaba seperti contohnya adalah KFC, Mc Donalds dan lain sebagainya. Itulah yang mendasari pemerintah untuk kemudian membuat peraturan tentang waralaba.

PT. Go-Jek Indonesia semakin lama semakin berkembang dengan pesat. Puluhan ribu orang sudah mengikatkan diri dalam perjanjian kemitraan dengan pola bagi hasil tersebut. Tidak hanya Go-Jek, Grab pun juga menggunakan pola kemitraan bagi hasil. Hal ini yang mendasari bahwa seharusnya pemerintah juga harus membuat peraturan yang mengatur tentang pola kemitraan bagi hasil seperti halnya pola kemitraan waralaba. Salah satunya dengan cara memberikan semacam guidelines (panduan) dalam pembuatan perjanjian kemitraan di dalam peraturan tersebut. Dengan adanya guidelines yang diberikan pemerintah, diharapkan tidak ada pihak yang dirugikan atau terpaksa.

Kemudian dalam Pasal 30 PP No. 17 Tahun 2013 juga disebutkan bahwa pemerintah dan pemerintah daerah berperan dalam perjanjian kemitraan ini baik dalam pengaturan, pemberian data dan informasi, pengembangan proyek percontohan kemitraan, serta pemantauan dari proses kerjasama kemitraan. Sedangkan tugas untuk

28 Philipus M. Hadjon, Perlindungan Hukum Bagi Rakyat Indonesia, (Surabaya: Bina Ilmu, 1987), at 30. 
mengawasi dipegang oleh Komisi Pengawas Persaingan Usaha (KPPU). Dengan demikian seharusnya pemerintah dan pemerintah daerah harus turut berperan dalam proses pembuatan perjanjian kemitraan. Dalam kasus Go-Jek ini pemerintah diharuskan membuat peraturan tentang kemitraan bagi hasil, dan pemerintah daerah juga berhak untuk mengatur dengan membuat Peraturan Daerah untuk beroperasinya ojek daring di daerahnya. Hal tersebut dilakukan untuk menciptakan perlindungan hukum dan kesetaraan bagi kedua pihak dalam pembuatan perjanjian kemitraan, sehingga tidak menimbulkan masalah dalam pelaksanaannya.

\section{B. Perlindungan Hukum Represif}

Perlindungan hukum represif merupakan perlindungan akhir setelah terjadinya suatu pelanggaran atau sengketa berupa sanksi seperti denda, penjara, dan hukuman tambahan. ${ }^{29}$ Perlindungan hukum yang represif bertujuan untuk menyelesaikan sengketa penanganan perlindungan hukum oleh Peradilan Umum dan Peradilan Administrasi di Indonesia termasuk kategori perlindungan hukum ini. Prinsip perlindungan hukum terhadap tindakan pemerintah bertumpu dan bersumber dari konsep tentang pengakuan dan perlindungan terhadap hak-hak asasi manusia diarahkan kepada pembatasan-pembatasan dan peletakan kewajiban masyarakat dan pemerintah. Prinsip kedua yang mendasari perlindungan hukum terhadap tindak pemerintahan adalah prinsip negara hukum. Dikaitkan dengan pengakuan dan perlindungan terhadap hak-hak asasi manusia, pengakuan dan perlindungan terhadap hak-hak asasi manusia mendapat tempat utama dan dapat dikaitkan dengan tujuan dari negara hukum..$^{30}$

Upaya perlindungan hukum secara represif ini dibutuhkan dalam hal terjadi peselisihan atau sengketa antara Go-Jek, AKAB, dan mitra. Mengingat adanya kemungkinan terjadi perselisihan, biasanya di dalam perjanjian telah dicantumkan tata cara penyelesaian perselisihan. Dalam perjanjian kemitraan telah tertuang klausula tentang penyelesaian sengketa pada Pasal 5.l yang berbunyi pertama, mitra dengan ini membebaskan GO-JEK dan AKAB dari segala macam tuntutan, gugatan, atau tindakan hukum lainnya, dalam bentuk apapun baik gugatan perdata maupun gugatan pidana, terkait dengan jasa yang ditawarkan,disediakan, diselenggarakan atau diselesaikan oleh mitra melalui Aplikasi GO-JEK.

Selanjutnya, apabila timbul perselisihan sehubungan dengan penafsiran dan/atau pelaksanaan dari Perjanjian ini maka GO-JEK, AKAB dan mitra sepakat untuk menyelesaikan perselisihan dimaksud secara musyawarah. Langkah yang diambil ketika perselisihan tidak dapat terselesaikan secara musyawarah maka dengan tidak mengurangi hak GO-JEK, AKAB dan mitra sepakat untuk menyelesaikan perselisihan, mengajukan laporan, gugatan atau tuntutan baik perdata maupun pidana melalui Pengadilan Negeri, Kepolisian dan instansi terkait lainnya dalam wilayah Negara Republik Indonesia.

\footnotetext{
29 Muchsin, supra note 27 at 20.

30 Philipus M. Hadjon, supra note 28 at 30.
} 
Berdasarkan klausula perjanjian kemitraan tersebut telah jelas disebutkan apabila timbul perselisihan antara Go-Jek, AKAB, dan mitra maka penyelesaiannya dilakukan secara musyawarah. Namun apabila perselisihan yang dimaksud tidak dapat diselesaikan secara musyawarah maka mereka sepakat untuk menyelesaikannya melalui jalur pengadilan di Pengadilan Negeri Jakarta Selatan.

Dalam klausula perjanjian kemitraan di atas sangat memberatkan pihak mitra yang ingin berperkara jika proses peradilan harus dilakukan di Pengadilan Negeri Jakarta Selatan. Seandainya mitra mempunyai domisili di Manado maka proses pengadilan sangat menyusahkan yaitu dari segi waktu, biaya dan efisiensi, dikarenakan pihak mitra yang ingin memperkarakan harus berangkat ke Pengadilan Jakarta Selatan untuk menyelesaikan perkara perselisihan. Seharusnya pihak Go-Jek harus mempunyai cabang perusahaan di setiap daerah dimana Go-Jek tersebut beroperasi, hal tersebut untuk memudahkan penyelesaian perselisihan dengan mitra baik itu melalui jalur nonlitigasi atau litigasi. Dengan adanya cabang dari perusahaan Go-jek juga dapat memudahakan pengawasan terhadap mitra sehingga pelayanan terhadap konsumen Go-Jek juga semakin berkualitas.

\section{PENUTUP}

Pengaturan ojek daring sampai saat ini belum diatur dalam perundang-undangan di Indonesia. Apabila mengacu pada Pasal 1 angka 10, Pasal 137 ayat (2), dan Pasal 138 ayat (3) UU No. 22 Tahun 2009, sepeda motor hanya termasuk dalam klasifikasi kendaraan bermotor umum. Ojek daring dalam kesehariannya bekerja layaknya angkutan orang dengan kendaraan bermotor umum tidak dalam trayek karena tidak mempunyai tujuan perjalanan tetap serta lintasan tetap. Dalam Pasal l angka 3 Permenhub No. PM 108 Tahun 2017 tidak menyebutkan sepeda motor sebagai angkutan orang dengan kendaraan umum tidak dalam trayek. Dari segi regulasi, ojek daring tidak mempunyai legalitas untuk beroperasi sebagai angkutan orang, tetapi hanya diakui sebagai kendaraan bermotor umum.

Perjanjian kemitraan adalah salah satu bentuk perjanjian tidak bernama seperti dalam Pasal 1319 KUHPerdata, sedangkan Pengaturan kemitraan diatur dalamPasal 1 angka 4 PP No. 17 tahun 2013. Perjanjian kemitraan antara Go-Jek, AKAB, dan mitra merupakan perjanjian yang berbentuk baku (standart contract). Dalam Pasal 2 (c) dan Pasal 5.2 (c) perjanjian kemitraan menunjukkan bahwa Go-Jek dan AKAB atas dasar pertimbangannya sendiri dapat mengubah atau menambahkan persyaratan tanpa turut andil dari pihak mitra. Selain itu dalam Pasal 3.3 (a) dan (b) perjanjian kemitraan, besarnya persentase bagi hasil tidak disebutkan dengan jelas. Dari klausula-klausula tersebut menunjukkan bahwa masih banyak ditemukan model perjanjian baku yang berpotensi mengandung cacat kehendak, yakni penyalahgunaan keadaan, cenderung dianggap berat sebelah, tidak seimbang, dan tidak adil. Dengan demikian, pihak yang lemah daya tawar-nya hanya sekedar menerima segala isi perjanjian dengan terpaksa (taken for granted) sebab apabila ia mencoba menawar dengan alternatif lain 
kemungkinan besar akan menerima konsekuensi kehilangan apa yang dibutuhkan. Dalam perjanjian kemitraan ini, Go-Jek dan AKAB sebagai pihak yang mempunyai daya tawar kuat sedangkan mitra sebagai pihak yang mempunyai daya tawar lemah.

Upaya hukum dalam memberikan perlindungan hukum terhadap mitra dapat dilakukan melalui perlindungan hukum preventif dan perlindungan hukum represif. Perlindungan hukum preventif dapat dilakukan oleh pemerintah melalui peraturan perundang-undangan yang dikeluarkan. Dengan berkembangnya pola kemitraan bagi hasil yang dituangkan dalam perjanjian kemitraan, seharusnya pemerintah membuat peraturan untuk memberikan perlindungan hukum bagi pihak dalam perjanjian kemitraan bagi hasil tersebut, seperti telah diaturnya mengenai pola kemitraan waralaba. Sedangkan perlindungan hukum represif dapat dilakukan jika terjadi perselisihan atau sengketa. Dalam Pasal 5.l. perjanjian kemitraan telah tertuang klausul tentang penyelesaian sengketa, tetapi klausula dalam perjanjian kemitraan tersebut memberatkan mitra, dikarenakan mitra harus memperkarakan masalahnya dengan PT. Go-Jek Indonesia di Pengadilan Jakarta Selatan.

Oleh karena itu, untuk menjamin kepastian hukum adanya ojek daring di Indonesia, maka pemerintah melalui Kementerian Perhubungan harus menjamin legalitas beroperasinya ojek daring yaitu dengan membuat peraturan tentang angkutan daring khususnya ojek daring. Pemerintah seharusnya juga membuat peraturan yang mengatur tentang pola kemitraan bagi hasil. Salah satunya dengan cara memberikan semacam panduan dalam pembuatan perjanjian kemitraan. Dengan adanya panduan yang diberikan pemerintah, diharapkan tidak ada pihak yang dirugikan atau terpaksa. Selain itu, dikarenakan penyalahgunaan keadaan (misbruik van omstandigheden) sebagai cacat kehendak baru belum diatur secara jelas dalam KUHPerdata, maka perlu ditinjau kembali dan melakukan perombakan-perombakan termasuk mengakomodasi ajaran penyalahgunaan keadaan dalam hukum perjanjian nasional kita di masa yang akan datang, mengingat persoalan-persoalan yang ada dari perkembangan-perkembangan kehidupan masyarakat. PT. Go-Jek Indonesia seharusnya mempunyai cabang perusahaan di setiap daerah dimana mitra Go-Jek tersebut beroperasi. Hal tersebut untuk memudahkan penyelesaian perselisihan dengan mitra baik itu melalui jalur nonlitigasi atau litigasi. Dengan adanya cabang dari perusahaan Go-Jek juga dapat memudahkan pengawasan terhadap mitra sehingga pelayanan terhadap konsumen GoJek juga semakin berkualitas. Seperti halnya pekerja/buruh, sebaiknya para mitra membuat serikat atau organisasi yang bertujuan untuk memberikan perlindungan, pembelaan hak dan kepentingan, serta meningkatkan kesejahteraan bagi para mitra. 


\section{DAFTAR PUSTAKA}

H. Salim HS, Perkembangan Hukum Kontrak di Luar KUH Perdata, (Jakarta: PT. Raja Grafindo Persada, 2006).

Henry P. Pangabean, Penyalahgunaan Keadaan (Misbruik Van Omstandigheden) Sebagai Alasan (Baru) Pembatalan Perjanjian, (Yogyakarta: Liberty, 2010).

Hernoko \& Agus Yudha, Asas Proporsionalitas dalam Kontrak Komersial Edisi l, (Yogyakarta: Laksbang Mediatama bekerja sama dengan Kantor Advokat "Hufron \& Hans Simalea", 2008).

Ian Linton, Kemitraan Meraih Keuntungan Bersama, (Jakarta: Hailarang, 1997).

J.S. Badudu \& Mohammad Zain, Kamus Umum Bahasa Indonesia, (Jakarta: PT. Intergraphic, 1994).

Khairandy, Ridwan, Hukum Kontrak Indonesia dalam Perspektif Perbandingan (Bagian Pertama), (Yogyakarta: FH UII Press, 2013).

Muchsin, Perlindungan dan Kepastian Hukum bagi Investor di Indonesia, (Surakarta: Universitas Sebelas Maret, 2003).

Philipus M. Hadjon, Perlindungan Hukum Bagi Rakyat Indonesia, (Surabaya: Bina Ilmu, 1987).

Rendy Saputra, Kedudukan Penyalahgunaan Keadaan (Misbruik van Omstandigheden) dalam Hukum Perjanjian Indonesia, (Yogyakarta: Gajah Mada University Press, 2016).

Satjipto Raharjo, Ilmu Hukum, (Bandung: PT. Citra Aditya Bakti, 2000).

Vuchic, Vukan R, Urban Passenger Transportation Modes, Public Transportation, Second Edition, (New Jersey: eds. Gray, George E dan Hoel, Lester A, Prentice Hall, Englewood liffs, 1992).

Gunawan \& Johanes, "Reorientasi Hukum Kontrak di Indonesia", (2003) Jurnal Hukum Bisnis: Vol. 22 No. 6.

"Kehadiran Ojek Online Kurangi Pengangguran - Bisnis Liputan6.com", online: 〈https://www.liputan6.com/bisnis/read/2645780/kehadiran-ojek-online-kurangipengangguran>.

"Tentang Kami | GO-JEK Indonesia”, online: 〈https://www.go-jek.com/about/〉.

"GO-JEK Indonesia", online: 〈https://www.go-jek.com/〉.

"Kisruh Demo Driver Ojek Online di DPR, Go-Jek Bakal Lakukan Apa? - Tekno Liputan6.com", online: 〈https:/www.liputan6.com/tekno/read/3483830/kisruhdemo-driver-ojek-online-di-dpr-go-jek-bakal-lakukan-apa〉. 
54 | Perlindungan Hukum Mitra Ojek Daring di Indonesia

This page is intentionally left blank 